\title{
砂丘地における乾砂層の蒸発抑制効果
}

\author{
竹田 信*
}

\section{Restriction of Evaporaion Caused by Dry Sand Layer on Syounai Dune}

\author{
Shin Takeda*
}

\begin{abstract}
It is expected that permeable dune sand areas have high potential of recharge to groundwater. The purpose of this paper is to clarify the soil moisture movement mechanism in unsaturated zone on the bare soil surface site on the Syounai Dune area. Actual evaporation during11 fine weather days was about $5-26 \%$ of the Penman potential evapo-transpiration. Evaporation experiment indicated that the thickening of dry sand layer restricted evaporation. As the result that the dry sand layer restrained evaporation, we could expect that the amount of recharge in the sand dune area increased relatively.
\end{abstract}

key words: dune, dry sand layer, evaporation

\section{要 旨}

浸透能が高く地下水の涵養域である砂丘地におい て不飽和带土壤水分の動態について調査を行った。 夏季の11日間無降雨期間において、庄内砂丘地域の 裸地における土壤水分を観測し、不飽和带の水収支 から裸地での実蒸発量の推定を試みた。この実蒸発 量はペンマン法により推定される可能蒸発散量の 5 〜26\%に相当した。裸地からの実蒸発量がこの様に 小さい值になった理由として、地表面に形成される 乾砂層の蒸発抑制効果が考えられる。このことは裸 地を想定した本研究でのカラム実験においても実証

*(侏)東芝 研究開発センター 環境技術研究所
された。蒸発量が乾砂層によって抑制される砂丘地 では、相対的に降雨量に対する涵養量の割合が大き くなることを示唆した。

\section{1. はじめに}

砂地は保水性が低く、そこに生育する植物は風害 を受け易いことから、「砂丘は不毛の地である」と いわれてきた。しかし砂丘地の裸地地表面は極度に 乾燥した乾砂層であるが(松田ほか，1977、宮崎・ 雨宮，1973、など)、その直下は湿潤であるという 土壤水分の特徵が知られるようになり、近年の地下 水利用と農業技術の発展と相まって砂丘地農業を可 能にした。またオランダでは浸透能の高い砂地に人 
工涵養施設を建設し成果をあげている(佐倉、1990)。 このように砂芹地などの砂質地域は地下水婳養量が 多いことが尔想され、水資源の供給源として注目さ れる。

砂丘地における乾砂層は厚さ数 $\mathrm{cm}$ で、層内部の 体積含水率は非常に小さく、風乾状態に近い。一般 に砂丘砂の乾砂層はそれ自身白い色を呈して扔り、 黒い下部の層との境界は色によって判断できる。野 村・井上(1979) は鳥取砂丘にて散水後の乾砂層の発 達について触れ、乾砂層厚は日変化を示しつつ漸増 することを確認した。さらに表層付近の土袞水分は 地温と密接に関係し、地温が降下すると土壤水分が 増加するという凝縮のプロセスを推察した。 Kobayashi et al. (1991) は乾砂層厚の変化、夜間凝 縮のメカニズムを 3 層モデルで説明した。即ち、下 層から液相で移動した土壤水分が、中層で 2 相(液 相・気相)に変化して移動し、上層では気相で通過 し蒸発する、というモデルである。このモデルでは 上層を乾砂層、中層を土壤水分プロファイルが急激 に変化する層、つまり乾砂層下部を想定している。 そして湿潤な下層からの水分上昇フラックスが時間 的にほぼ一定であるのに対して、上層から上方へ移 動する水蒸気量(蒸発速度)が地温に伴って日変化を 示すために、その境界に位置する中層や上層の土壤 水分が日変化を示すと説明した。この研究は蒸発の メカニズムを詳細に検討したものとして非常に注目 すべきものである。しかし彼らの示した 3 層モデル では地表表層に近い部分が対象となっているため、 ゼロフラックス面(以下、ZFP、と略す)については まったく触れていない。この他にも、砂丘地に扔け る蒸発量を推定・算出した研究、乾砂層と地温・熱 収支との関係を考察した例は数多い。しかしいずれ も地表表層付近に主眼が扔かれているため、これら の現象が水循環の一過程であるとする水文学的研究 に位置づけられるものはほとんどない。

本研究は浸透能が高く地下水涵養域として期待さ れる砂丘地に扔ける不飽和帯土壌水分の動態に着目 し、日本で最大級を誇る庄内砂丘において現地観測 を行った。特に蒸発という水文現象に着目し、11日 間無降雨が連続した期間における裸地での不飽和帯 の土壤水分プロファイルを観測し、不飽和砂層中に おける土壤水分の移動機構を明らかにした。また同 期間における裸地での実蒸発量の推定を試み、各気 象要素から計算されるペンマン法による可能蒸発散
量と比較検討を行った。さらに蒸発メカニズムを検 討するために裸地を想定したカラム実験を行い、砂 丘地裸地地表面に形成される「乾砂層」と蒸発との 関係を検証した。

\section{2. 研究方法}

\section{1 研究地域の概要}

庄内砂丘は山形県庄内平野の海岸部に発達し、そ の規模は北の鳥海山山麓の吹浦から南は鶴岡市湯の 浜に至る延長 $33 \mathrm{~km}$ 、最大幅 $3 \mathrm{~km}$ 、最高点標高 $62.5 \mathrm{~m}$ 、 総面積はおよそ $80 \mathrm{~km}^{2}$ におよぶ。庄内砂丘は大きく 2 つの南北に延びる砂丘列からなり、西から第 1 砂 丘、第 2 砂丘と呼ばれる(第 1 図)。第 1 砂丘は海抜 10 15m で、頂部に幅約 $200 \mathrm{~m}$ ほどの人工防風林が 存在する。第 2 砂丘は海抜30～60m ほどで、東側が やや急斜し、東斜面の裾野には湧水が点在する。ま た第 2 砂丘は南部がやや高く、海岸線に直行する横 列砂丘群もいくつかみられる。両砂丘の間には海抜 $5 \sim 15 \mathrm{~m}$ の低地带及び緩斜面があり、中央低地(砂 丘低地)と呼ばれている。中央低地には海岸線に平 行な幅数 $\mathrm{m}$ の防風林が帯状に存在し、これは衛星 画像によっても識別できる。

\section{2 観測地点の概要}

本研究では中央低地のほぼ中央、酒田市最南端に 位置する山形県立砂丘地農業試験場内で現地水文観 測を実施した。以下、本地点を裸地と呼ぶ。裸地は 試験場の気象観測施設に隣接し、丈が数 $10 \mathrm{~cm}$ の 雑草がまばらに地表を覆う。半径 $10 \mathrm{~m}$ 以内には潅水 設備はなく、自然の状態と環境条件は同じとみるこ とができる。裸地の地表標高は $10.58 \mathrm{~m}$ である。裸 地の新砂丘砂について粒度試験を行った結果、樑度 による粒径の差はほとんどなくほぼ均質であるとい える。また固相率はいずれの深度も50～ $55 \%$ で、明 らかな土層構造の相違は認められなかった。

\section{3 観測方法}

不飽和砂層中の土壤水分の移動機構を把握するた め、圧力水頭及び土壤水分量の測定を行った。観測 は1989年および1990年の夏季に集中してそれぞれ約 2 ケ月間ずつ行った。圧力水頭は水銀マノメー夕式 テンシオメータ(埋設深度は $20 \mathrm{~cm} 、 50 \mathrm{~cm} 、 100 \mathrm{~cm}$ 、 $200 \mathrm{~cm} 、 300 \mathrm{~cm})$ で、土壤水分量は中性子水分計でそ 


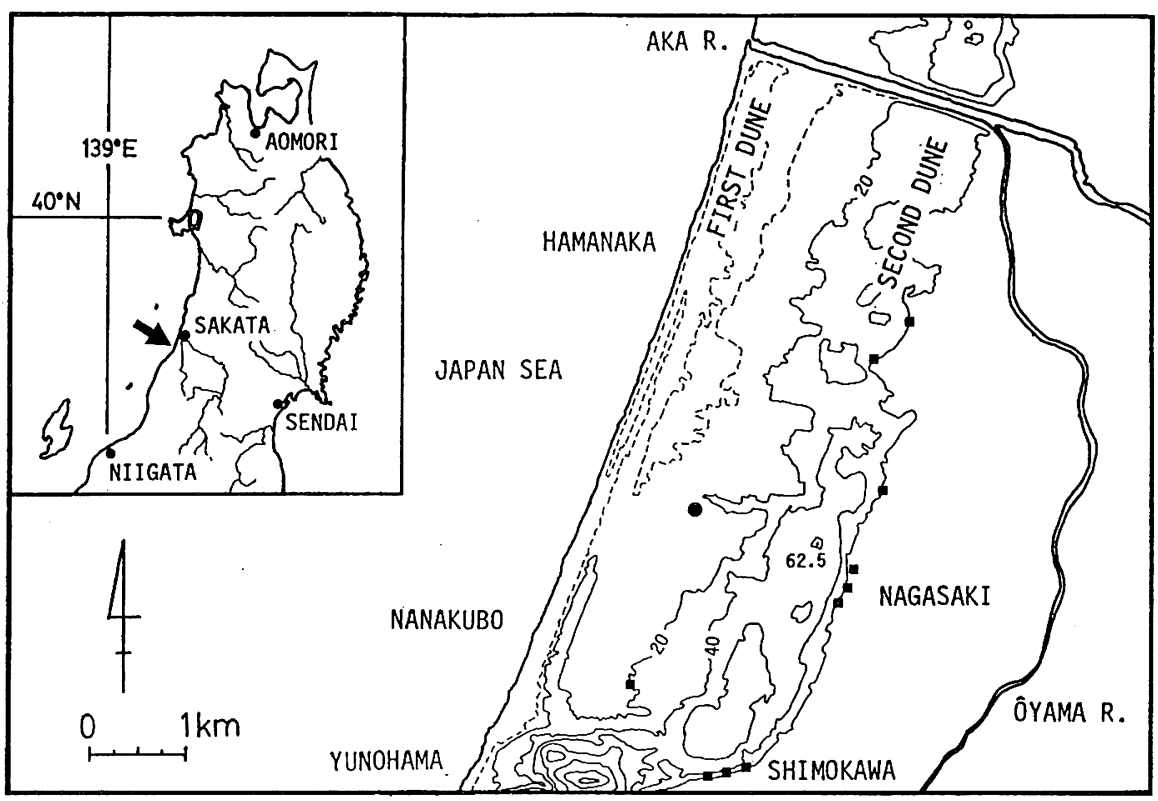

第 1 図 調査地域

Fig.1. Study area. Solid squares indicate springs, solid circle indicates observation site.

れぞれ観測した。中性子水分計による土壤水分量の 計測深度は深度 $20 \mathrm{~cm} 、 50 \mathrm{~cm} 、 75 \mathrm{~cm}$ 、以下 $25 \mathrm{~cm}$ ごと 地下水面までとした。な扮本研究で使用した機器は、 MODEL SRM-1D、直読式挿入型である。本機種は 速中性子源と熱中性子検出管が 1 本のプローブに組 み込まれているもので、プローブ長が $685 \mathrm{~mm}$ 、直径 が $40 \mathrm{~mm}$ 、線源は ${ }^{252} \mathrm{Cf}$ の $50 \mu \mathrm{Ci}$ 、検出は ${ }^{3} \mathrm{He}$ 管であ る。アクセスチューブは鉄製で、外径 $60.5 \mathrm{~mm}$ 、内 径 $52.9 \mathrm{~mm}$ 、埋設深度は $450 \mathrm{~cm}$ である。

本研究ではペンマン法による可能蒸発散量(以下、 ペンマン蒸発散量、と略して呼ぶ)は中尾(1971)に 従い、以下の式によって算出を行った。

$$
\begin{aligned}
\mathrm{E}_{\mathrm{o}}= & \frac{0.417 \Delta *(\mathrm{He} / 59)+0.27 \mathrm{E}_{\mathrm{a}}}{0.417 \Delta+0.27} \\
\mathrm{H}_{\mathrm{e}}= & (1-\mathrm{r}) \mathrm{R}_{\mathrm{A}}-\delta \mathrm{T}^{4}\left(0.56-0.078 \sqrt{\mathrm{e}_{\mathrm{d}}}\right) \\
& (0.1+0.9 \mathrm{n} / \mathrm{N}) \\
\mathrm{E}_{\mathrm{a}}= & 0.26(0.5+54 \mathrm{u} / 100)\left(\mathrm{e}_{\mathrm{a}}-\mathrm{e}_{\mathrm{d}}\right)
\end{aligned}
$$

ここで、 $\mathrm{E}_{0}:$ 蒸発量 $[\mathrm{mm} / \mathrm{day}]$

$$
\begin{aligned}
\Delta & : \text { 気温の飽和蒸気圧勾配 }\left[\mathrm{mb} /{ }^{\circ} \mathrm{K}\right] \\
\mathrm{r} & : \text { アルベド }(=0.3) \\
\mathrm{R}_{\mathrm{A}} & : \text { 日射量 }\left[\mathrm{cal} / \mathrm{cm}^{2} / \mathrm{day}\right]
\end{aligned}
$$

$$
\begin{aligned}
\delta \quad: \text { Stefans'const. }\left[\mathrm{cal} / \mathrm{cm}^{2} / \mathrm{K}^{4} / \mathrm{day}\right](= \\
\\
\left.1.183 \times 10^{-7}\right) \\
\mathrm{T} \quad: \text { 気温 }\left[{ }^{\circ} \mathrm{K}\right] \\
\mathrm{n} / \mathrm{N}: \text { 日照率 }(\text { 可照時間に対する日照時間 }) \\
\mathrm{u} \quad: \text { 風速 }[\mathrm{m} / \mathrm{day}] \\
\mathrm{e}_{\mathrm{a}}: \text { 飽和水蒸気压 }[\mathrm{mb}] \\
\mathrm{e}_{\mathrm{d}} \quad: \text { 蒸気压 }[\mathrm{mb}]
\end{aligned}
$$

なお、ペンマン蒸発散量は「丈の短い草地に十分 水を供給した場合に生じる蒸発散量」であり、地表 面が濡れている場合には精度良く推定することが可 能である。本研究では裸地に隣接した試験場の気象 観測施設での観測值を用い、各気象要素は日平均・

日総量の值を使用した。

\section{3. 観測結果}

\section{1 土锖水分プロファイルの変化}

11日間無降雨が連続した夏季の期間に扔ける裸地 での土壤水分プロファイルの変化を第 2 図に示す。 11 日間の無降雨期間は1989年 8 月 15 日から 26 日、 1990年 7 月 27 日から 8 月 7 日である。両期間の先行 降雨は 1989 年 8 月 14 日 $7.5 \mathrm{~mm} 、 1990$ 年 7 月 25 日 


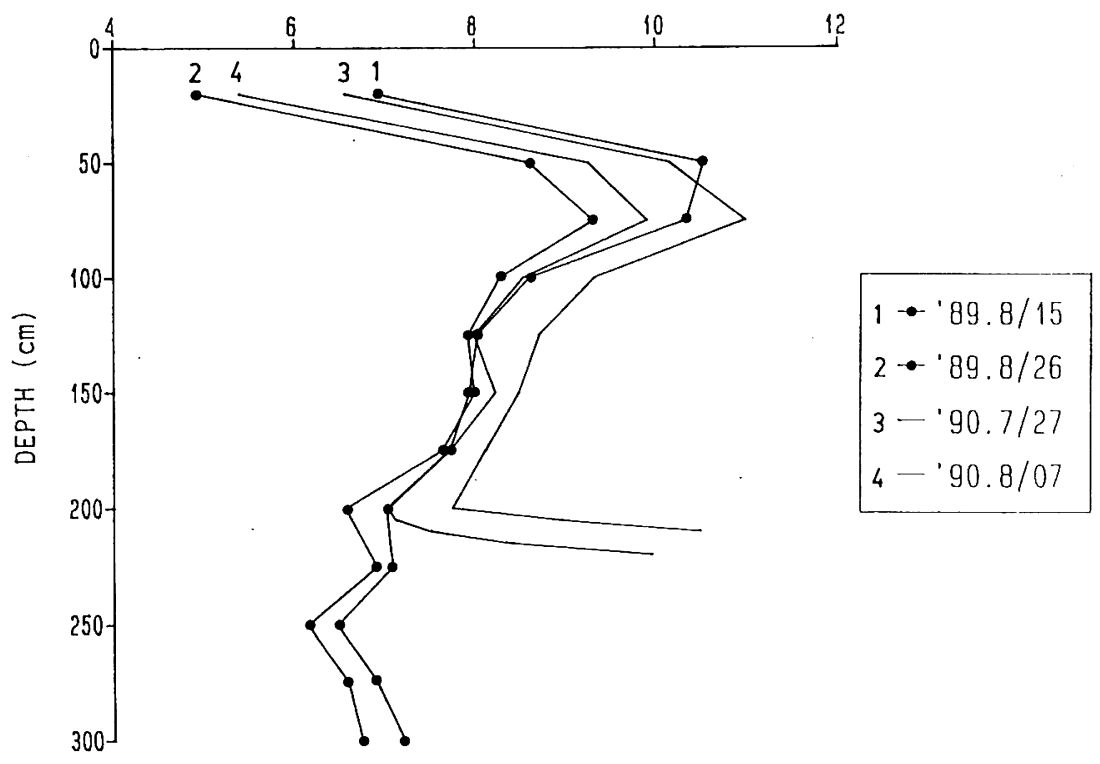

第 2 図裸地における土壤水分プロファイルの変化

Fig.2. Change in the profile of volumetric water content on the bare soil surface site.

$0.5 \mathrm{~mm}(7$ 月 19 日 $8.5 \mathrm{~mm})$ である。地下水位の深度は 1989 年 8 月 15 日 $355.5 \mathrm{~cm}$ 、同 26 日 $368.0 \mathrm{~cm} 、 1990$ 年 7 月 27 日 $238.0 \mathrm{~cm} 、 8$ 月 7 日 $251.0 \mathrm{~cm}$ である。とも に11日間の無降雨期間で地下水位は約 $13 \mathrm{~cm}$ ほど降 下している。毛管水帯はいずれの期間とも約 $50 \mathrm{~cm}$ であり、第 2 図の1990年の土壤水分プロファイルに は深度 $200 \mathrm{~cm}$ 付近に毛管水帯の最上部がみられる。 土壤水分プロファイルの形は無降雨期間を通してほ ぼ一定で、特定の深度にピークをもち、深度の増加 とともに減衰する形を呈している。粒度分析の結果 から裸地での砂層はほほ均質であり、上述の土壤水 分プロファイルのピークは蒸発及び涵養が行われた 水分移動(再配分)の結果形成されたものと考えられ る。しかし、前述した粒度分析の精度では現れない 様な薄い細粒層の存在や、砂の締まり具合(固相率 の相違)といった微細な物理的な構造に影響してい る可能性もある。

同期間の水理水頭プロファイルの変化を第 3 図に 示す。同期間における水理水頭プロファイルの形か ら、深度 $50 \mathrm{~cm}$ 以深の土潩水分は常に下方へのフラッ クスをもっており、深度 $300 \mathrm{~cm}$ の水理水頭值はほほ 一定を保っていることが判る。地表面付近では蒸発
の影響がみられ、1989年 8 月 26 日の水理水頭プロ ファイルでは、樑度 $50 \mathrm{~cm}$ 以浅の土壤水分は上方に フラックスをもっていることが判る。

\section{2 裸地における夏季の実蒸発量}

固場容水量は通常、24時間排水させた後の土壌水 分と考えられている。砂の場合は排水の低减が長く、 排水を持続させる能力も大きいという報告 (Sakura、1983)もされているが、本研究では降雨 終了 24 時間後の土壤水分量を娄場容水量と仮定し た。また土壤水分量が圃場容水量に達した後では、 無降雨期間中に裸地の ZFP 以浅の不飽和带から減 少した土壤水分は蒸発によって減少した土壤水分に 等しいと仮定した。11日間の無降雨期間中、最も ZFPが梁い深度に位置した時点(11日目)のZFP梁 度は、1989年では深度 $50 \mathrm{~cm} 、 1990$ 年では深度 $20 \mathrm{~cm}$ である(第 3 図)。不飽和带土壤水分の水収支から 11 日間の無降雨期間における裸地での実蒸発量の推定 を行った(第 4 図)。その結果、裸地での実蒸発量は 1989 年では $9.7 \mathrm{~mm} 、 1990$ 年では $2.3 \mathrm{~mm}$ と算出され た。

同期間における、各気象要素から計算されるペン 
HYDRAULIC HEAD (cmH2O)

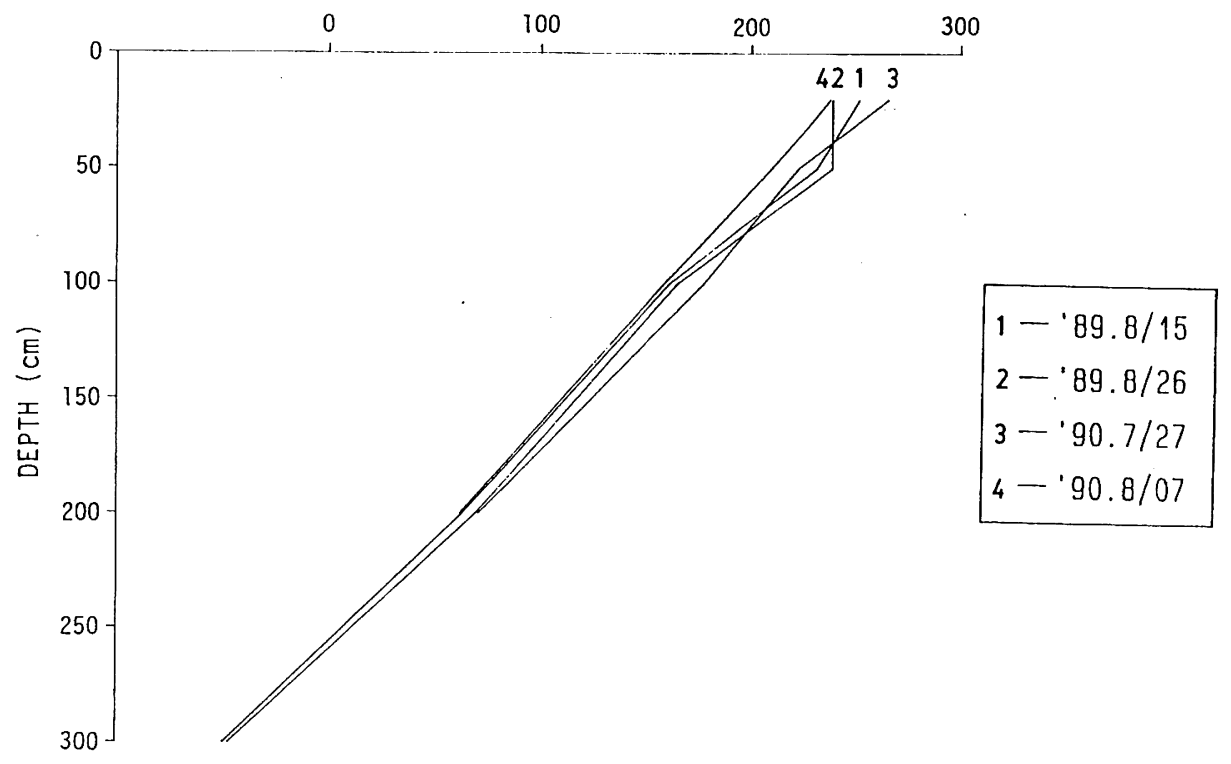

第 3 図 裸地における水理水頭プロファイルの変化

Fig.3. Change in the profile of hydraulic head on the bare soil surface site.

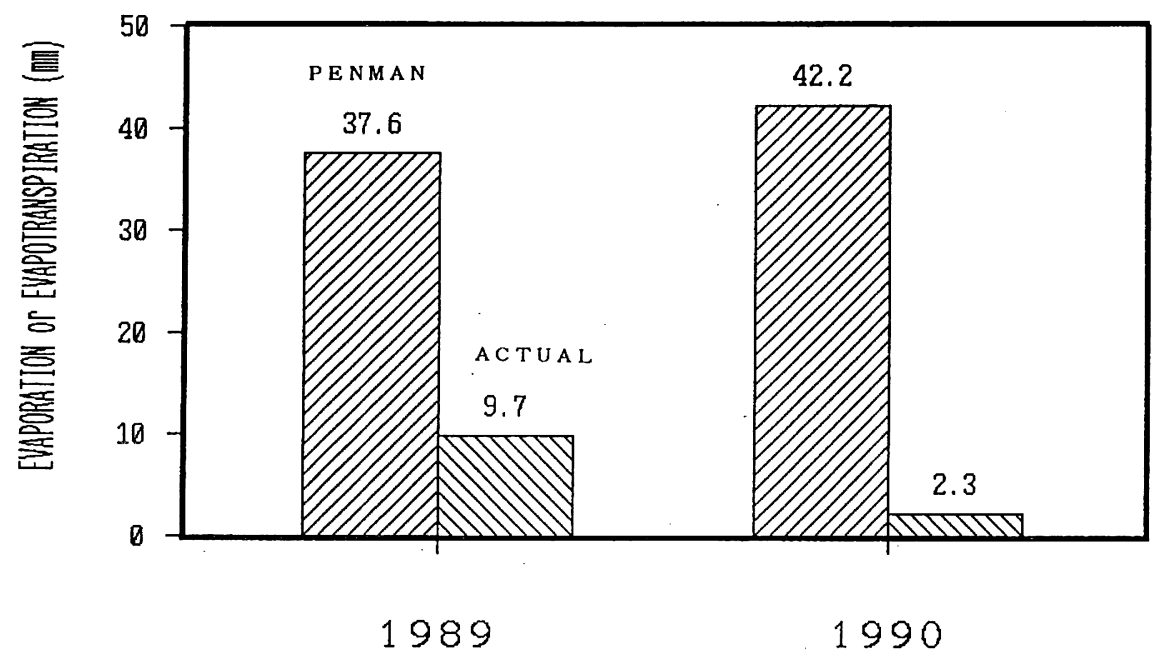

第 4 図 裸地における無降雨期間の実蒸発量とペンマン蒸発散量の比較

Fig.4. The comparison between actual evaporation and Penman potential evapotranspiration on the bare soil surface site. 
マン蒸発散量を求めた(第 4 図)。1989年および1990 年の11日間の平均気温、日照時間、日射量、平均風 速、平均湿度は、それぞれ $25.1^{\circ} \mathrm{C} 、 25.5^{\circ} \mathrm{C} 、 107.7 \mathrm{~h}$ 、 $127.8 \mathrm{~h} 、 240.3 \mathrm{MJ} 、 272.0 \mathrm{MJ} 、 1.8 \mathrm{~m} / \mathrm{sec} 、 1.5 \mathrm{~m} / \mathrm{sec} 、$ $79.5 \% 、 82.3 \%$ あ゙る。その結果、裸地でのペンマ ン蒸発散量は 1989 年では $37.6 \mathrm{~mm} 、 1990$ 年では $42.2 \mathrm{~mm}$ と算出された。以上の様に、不飽和帯の水 収支から求めた実蒸発量は、各気像要素加算出さ れたペンマン蒸発散量の 5 ２6\%にあたり、砂丘地 裸地での実蒸発量はペンマン蒸発散量に比べ非常に 小さいことが明らかとなった。

林・山野(1990)は裸地からの実蒸発量と自由水面 からの蒸発量を、日本とタンザニアの半乾燥地域で 比較検討した。彼らは土壤水分の飽和度と水面蒸発 量は直線的な比例関係であり、土壤水分の減少に 伴って蒸発量が減少することを指摘している。本研 究の裸地からの実蒸発量はペンマン蒸発散量の約半 分以下という值だが、この原因についても地表表層 の土潩水分との関係が注目される。

\section{4. 考察}

4. 1 蒸発のカラム実験の概要と実験結果

裸地に扔ける蒸発量が小さいことは、地表表層の 土壤水分と密接に関係していることが推察される。 本研究ではこのことに注目し、不飽和砂層中の土壤 水分の移動機構を明らかにするため庄内砂丘砂を用 いたカラム実験を行った。

実験には直径 $67 \mathrm{~mm}$ の透明塩ビパイプを用いた (第 5 図)。砂は水道水でよく洗浄し風乾した後、カ ラムを吒きながら均一になる様に充填した。地表面 から約 $130 \mathrm{ppm}$ の食塩水を滴下し、カラムからの排 出水の質と量がカラムへの供給水のそれと等しくな るまで滴下を続けた。初期状態は24時間排水後とし、 土柱表面上 $30 \mathrm{~cm}$ に $185 \mathrm{~W}$ 電球 3 個を設置して土柱 に熱を供給し蒸発を開始させた。地表面以外の部分 にはライトが当たらないようにアルミホイルで覆っ た。地表面には小型扇風機によって風を送り、室温 は約 $22^{\circ} \mathrm{C}$ の恒温に保った。地下水面は深度 $140 \mathrm{~cm}$ の 一定に保ち、流出量を測定した。

実験カラムは 2 本用意し、一方が圧力水頭観測用、 一方が分解型で土壤水分量測定用である。压力水頭 は水直結式のテンシオメータを15深度に設置して測 定した(第 5 図)。実際には地表面に最も近いテンシ

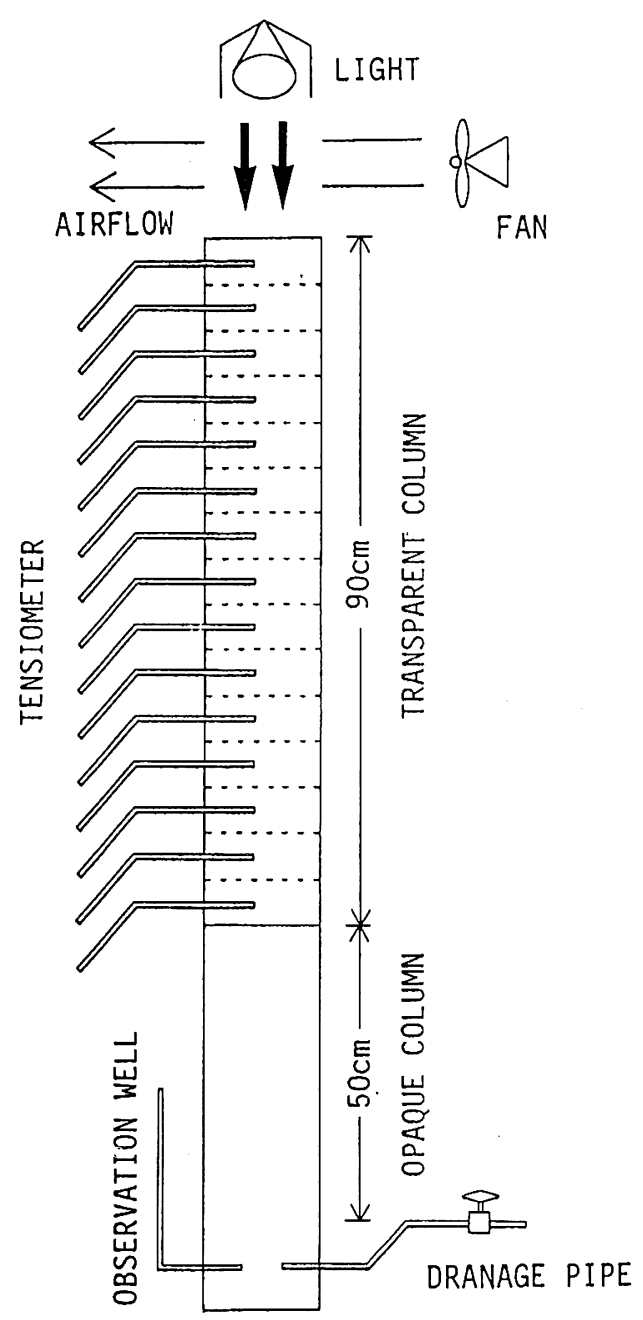

第 5 図 蒸発実験カラムの概要

Fig.5. Schematic diagram of the sand column experimental apparatus.

オメータは、土壤が風乾状態であったため観測不能 であった。土壤水分量は実験終了時に15のカラム (個々のカラムの高さは $6 \mathrm{~cm}$ ) に分解し、各カラム 単位で、100cc 採土管によって採土し炉乾法によっ て測定した。実験はまず初期の状態を把握し、次に 5 日間と10日間の実験をそれぞれ行った。5日間の 蒸発実験は10日間の実験での 5 日目の現象を捉えた ものと仮定して、蒸発開始時(以下、初期)、蒸発開 始後 5 日時 (以下、 5 日目)、蒸発開始後 10 日時(以下、 10日目)における観測結果について示す。 
水理水頭プロファイル、土壤水分プロファイルの 変化を第 6 図に示す。水理水頭值の基準は深度 $90 \mathrm{~cm}$ である。水理水頭プロファイルの形は表層に 近い部分が変化し、初期から9日目まではカラム全 層で鉛直下向きの動水勾配が観測された。水理水頭 勾配が鉛直上向きと下向きの境界にあたる ZFPは、 5 日目では深度 $8 \mathrm{~cm}$ より浅い深度に、10日目では ほぼ深度 $14 \mathrm{~cm}$ に位置した。土壇水分の变化は、深 度 $10 \mathrm{~cm}$ 以浅の地表面に近い部分の土壤水分が極度 に低下している。5日目まではカラム全層に渡って 土壤水分の減少がみられるが、深度 $20 \mathrm{~cm}$ 以深の土 壤水分には 5 日目以後 10 日目まで土壤水分の減少は ほとんどみられない。

カラムは透明であるので、乾砂層の成長の様子は 肉眼で観察できる(第 7 図)。本実験における乾砂層 の体積含水率は約 $0.5 \%$ であた。実験開始直後か ら層厚を増す乾砂層は、その成長速度を減速させな がら10日目には7.0 cmにまで及んだ。実験ごとによ る乾砂層厚の差やカラムごとの差は認められなかっ た。
4. 2 カラム実験における乾砂層の評価

カラム実験の土畩水分プロファイル(第 6 図)から カラム内の水収支計算によって 5 日間及び10日間の 蒸発量を求めた(第 1 表)。貯留減少量は地表面から 樑度 $90 \mathrm{~cm}$ までの各カラムの体積含水率に各カラム

第 1 表 蒸発実験におけるカラム内の水収支

Table Water balance of the sand column in the evaporation experiment.

\begin{tabular}{|c|c|c|c|}
\hline & \multicolumn{3}{|c|}{ 水収支 $\left(\mathrm{cm}^{3}\right)$} \\
\hline & 貯留減少 & 流出 & $\begin{array}{c}\text { 蒸発 } \\
\text { (水柱高) }\end{array}$ \\
\hline 5日目 & 46.55 & 25.55 & $\begin{array}{c}21.00 \\
(5.96 \mathrm{~mm})\end{array}$ \\
\hline 10日目 & 51.26 & 23.85 & $\begin{array}{c}27.41 \\
(7.77 \mathrm{~mm})\end{array}$ \\
\hline
\end{tabular}

HYDRAULIC HEAD (cmH2O)

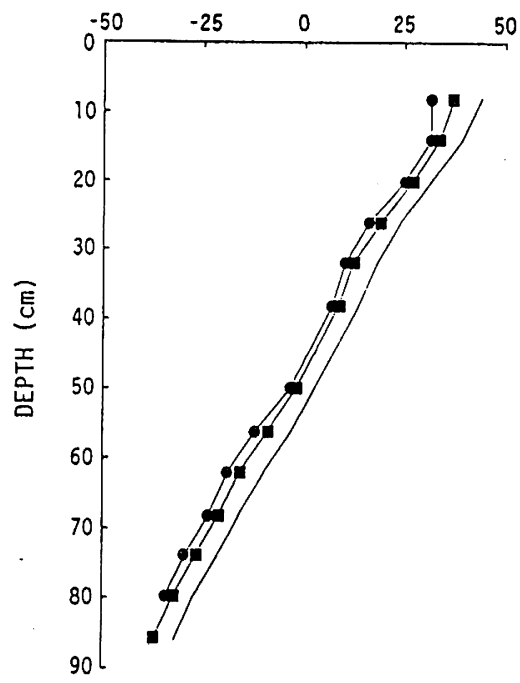

(a)
VOLUMETRIC WATER CONTENT (\%)

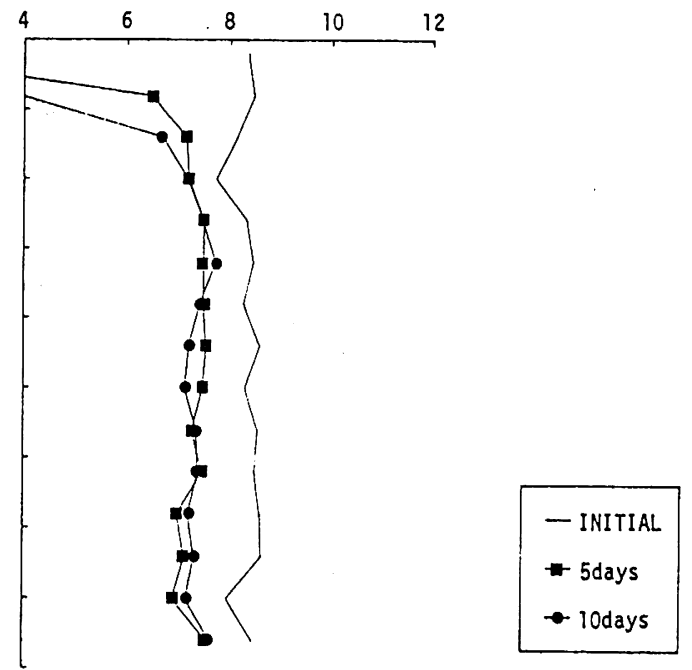

(b)

第 6 図 蒸発実験における （a) 水理水頭プロファイル、(b) 土㜔水分プロファイルの変化

Fig.6. Changes in the profiles of hydraulic head and volumetric water content in the evaporation experiment. 
LAPSE TIME (day)

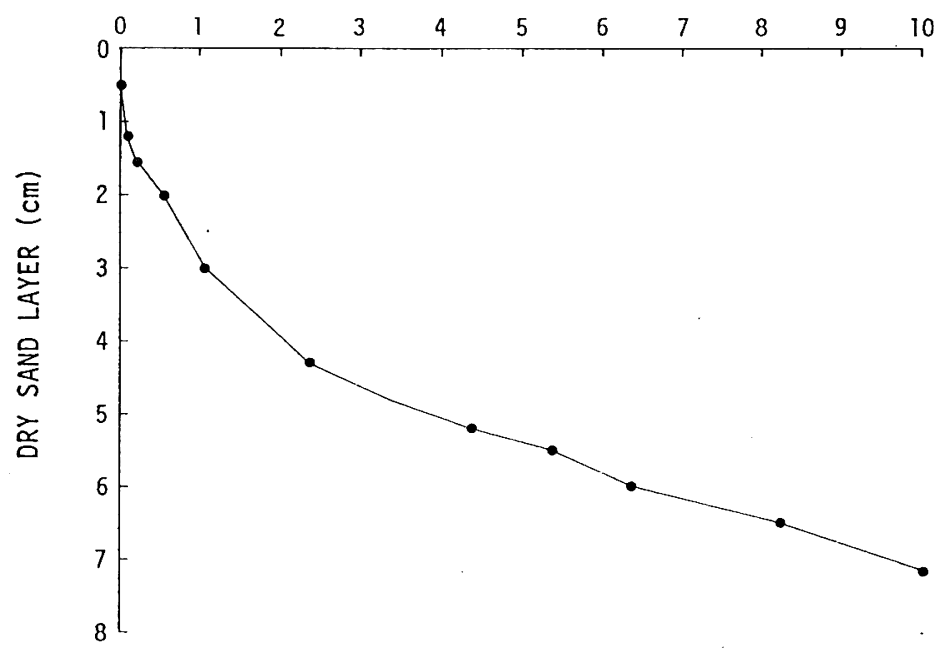

第7图 蒸発実験における乾砂層厚の变化

Fig.7. Change in the thickness of dry sand layer in the evaporation experiment.

の体積を乗じ、全カラムを合計した。ここでは、地 下水面は一定を保っているため毛管水帯の貯留变化 分は無視できるものと仮定した。蒸発量は貯留減少 量から流出量を差し引いた值で、カラム断面積で除 して水柱高に換算した。例えば 5 日目は、全カラム 内から貯留量 $46.55 \mathrm{~cm}^{3}$ が減少している。この值か ら 5 日間の流出量 $25.55 \mathrm{~cm}^{3}$ を差し引いた $21.00 \mathrm{~cm}^{3}$ が 5 日間の総蒸発量に当たる。この量をカラム断面 積 $35.26 \mathrm{~cm}^{2}$ で除した值 $5.96 \mathrm{~mm}$ は 5 日間の蒸発量 (水柱高)となる(第 1 表)。なお本実験で 5 日目の $(5$ 日間の実験の)流出量が10日目の(10日間の実験の) 流出量を上回っているが、この理由は不明である。 5 日間と10日間の実験は個々に行っており、実験の 再現性などに課題があると思われる。

本実験では、 5 日間の蒸発実験は10日間の実験で の 5 日目の現象を捉えたものと仮定している。従っ て10日間のうちで後半 5 日間の蒸発量は、10日目 $(7.77 \mathrm{~mm})$ から 5 日目 $(5.96 \mathrm{~mm})$ の蒸発量を差し引い た $1.81 \mathrm{~mm}$ と仮定できる。つまり10日間の後半 5 日 間の蒸発量 $(1.81 \mathrm{~mm})$ は、前半のそれ $(5.96 \mathrm{~mm})$ の 3 割であることが判る。実験条件の変化はないため、 この様な蒸発量の低下は地表面の土壤水分の減少と 関連があるものと考えられる(第 7 図)。5 日目以降、 深度 $20 \mathrm{~cm}$ 以深の土壤水分はほとんど变化せず、土
壤水分が減少したのは深度 $10 \mathrm{~cm}$ 以浅の地表面部分 に集中している。また実験開始直後から層厚を增す 乾砂層の成長は徐々に緩やかになっている。これら の実験結果より、乾砂層の存在は蒸発を抑制し、蒸 発量の低下と共に乹砂層の成長は緩やかになってい くことが明らかになった。この様に、乾砂層と蒸発 には相互に密接な関係があり、砂丘地裸地の水文現 象の一つとして非常に注目される。

本研究では現地水文観測によって夏季の11日間無 降雨が連続した期間における裸地での実蒸発量の推 定を試みたが、この值が各気象要素から計算される ペンマン蒸発散量に比べ 5 ～ $26 \%$ と小さい值になっ た。この様に乾砂層が成長する砂丘地裸地での蒸発 量が小さいこと、砂丘地裸地地表面に形成される乾 砂層が蒸発を抑制していることは、本研究の実験結 果から裏付けることができる。このことから、蒸発 量が乾砂層によって抑制される砂丘地では相対的に 降雨量に対する涵養量の割合が大きくなると考えら れる。特に豪雨直後の乾砂層の成長は、浸透した降 雨の蒸発を抑制し、涵養を助長させる働きをもって いると考えられる。つまり降雨終了直後から乾砂層 が成長し易い砂丘地などの砂質土壤の地域が、地下 水涵養に貢献しているということが推察される。

本研究では乾砂層の蒸発抑制効果について定性的 
に論じてきたが、未だ定量的な議論をするまでには 至っておらず、今後研究を深める予尘である。また 実験では 5 日間の実験を 10 日間の実験での 5 日目の 現象を捉えたものと仮定しているが、この点につい て実験の再現性などの課題があり、以後検討する必 要があろう。

\section{5.おわりに}

本研究では砂丘地裸地における不飽和帯土壤水分 の動態を明らかにするため、種々の現地観測やカラ ム実験を行った。そして乾砂層の蒸発抑制効果がみ られる砂丘地裸地では相対的に涵養量が多くなるこ とが明らかとなり、地下水涵養に寄与することが推 祭された。本研究で明らかとなったことは以下の通 りである。

1. 不飽和带土壤水分の水収支から、砂丘地裸地に おける夏季の 11 日無降雨期閒の実蒸発量を求め た。その結果、裸地での実蒸発量は各気象要素 から計算されるペンマン法による可能蒸発散量 の 5 〜 26\%と小さい值になった。

2. 砂丘地裸地を想定したカラム実験を行った。そ の結果、乾砂層の存在は蒸発を抑制し、蒸発量 の低下と共に乾砂層の成長は緩やかになってい くことが明らかになった。この乾砂層の蒸発抑 制効果は砂丘地裸地の水文現象の一つとして非 常に注目され、砂丘地での地下水涵養に大きく 貢献していると考えられる。

本研究を行うにあたり、千葉大学理学部地学科佐 倉保夫助教授には終始適切なご指導、ご鞭撻を頂き ました。東北農政局堀信美、長江亮二、中里裕臣各 氏には本研究を始めるに当たり、その機会を提供し て頂きました。農林水産省農業工学研究所の小前隆
美、今泉真之両氏には中性子水分計を借用するに際 して大変お世話になりました。本稿の作成には千葉 大学理学部地学教室の新藤静夫教授、宮内崇裕博士、 小野寺真一氏をはじめとする応用地学講座の方々に 貴重な助言と有益な御討議を賜りました。山形県立 砂丘地農業試験場の方々には観測場所を快く提供し て頂きました。以上の方々に心より感謝いたします。 なお本研究は1991年度日本水文科学会学術大会で 発表した内容を骨格として扔り、千葉大学へ提出し た平成 3 年度修士論文の一部を加筆・修正したもの である。

\section{参 考 文 献}

佐倉保夫 (1990)：地下水の分布と利用、大原隆・西田孝編 『地球環境の変容』、朝倉書店、p. $89 \sim 95$.

中尾欣四郎 (1971)：湖沼水位の安定性についての研究. 北 海道大学地球物理学研究報告、25、p.42 49.

野村安治・井上光弘(1979)：散水後の乾砂層の発達とその 特性. 鳥取大砂丘研報、18、p.27 33.

林 正貴・山野芳樹(1990)：タンザニアと日本における裸 地の実蒸発量の比較. 日本水文科学会1990年度学術大会 予稿集.

松田昭美 - 神近牧男 - 安東登志広(1977)：砂丘地地表付近 における温度の垂直分布について，鳥取大砂丘研報告、 16、 p. $9 \sim 13$.

宮崎 毅・雨宮 悠(1973)：土壤水分移動における地温と 凝縮の影響について. 農土論集、48、p.16〜22.

Hanks, R. J. (1967): Evaporation of water from soil as influenced by drying with wind or radiation. Soil Sci. Soc. Am. Proc., 31, p. 593 598.

Higuchi, M. (1984): Numerical simulation of soil-water flow during drying a non-homogeneous soil. J. Hydrol., 71 , p303-334.

Kobayashi, T., Matsuda, A., Kamichika, M. and Yamamura, Y. (1991): Why the Thickness of the Dry Surface Layer in Sand Dune Field Exhibits a Diurnal Variation? J. Agr. Met., 47, p. 3-9. 